\title{
Strategi Meningkatkan Kemampuan Bahasa Inggris Mahasiswa STMIK STIKOM Indonesia Melalui Pemanfaatan Video Online Youtube
}

\author{
I Kadek Agus Bisena ${ }^{1}$, Ni Nyoman Ayu J. Sastaparamitha ${ }^{2}$ \\ 1,2, Program Studi Teknik Informatika \\ STMIK STIKOM Indonesia \\ Email: agus.bisena@stiki-indonesia.ac.id; aj_sasta@yahoo.com
}

\begin{abstract}
The current generation that is known as the millennium generation is synonymous with technological and educational developments. This phenomenon is a strategy that can be used by advocates of foreign languages, especially English in packaging a material to be taught. One of the choices is the use of youtube online videos as supporting teaching materials. The technology is very easy to access, especially STMIK STIKOM Indonesia students, where almost all students have the youtube application. This study uses a qualitative description analysis method to see how attractive YouTube videos are among students, as well as video criteria that are considered interesting by them. The results of the study are packaging of youtube online videos that are tailored to the teaching material delivered to STMIK STIKOM Indonesia students, as the lecturers' handlers and student references in their own creative learning.
\end{abstract}

Key words: youtube, video online, online learning strategy

\section{Latar Belakang}

Bahasa Inggris merupakan bahasa internasional yang digunakan oleh banyak negara dan dikenal oleh semua bangsa didunia. Hal ini membuat bahasa Inggris menjadi bahasa global. Sebagai bangsa Indonesia yang juga tidak luput dari pergaulan internasional baik dalam dunia politik, sosial, budaya maupun bisnis, maka masyarakat Indonesia juga dituntut untuk mampu menguasai bahasa Inggris. Saat ini terlebih lagi Indonesia sudah masuk dalam Masyarakat Ekonomi Asia (MEA) dimana generasi muda terutamanya dituntut untuk mampu bersaing menghadapi persaingan global, sehingga kesempatan kita tidak diambil oleh warga asing.

STMIK STIKOM Indonesia merupakan salah satu sekolah tinggi IT di Bali yang sangat berkomitmen untuk menghasilkan lulusan yang kompeten dan mampu bersaing dalam komunitas global. Dengan kolaborasi kemampuan informasi teknologi dengan kemampuan bahasa Inggris diyakini akan mampu membuka peluang yang lebih besar terhadap lulusan STMIK STIKOM Indonesia dalam dunia kerja modern saat ini. Usaha-usaha riil telah dilakukan institusi mulai dari penambahan mata kuliah bahasa Inggris dari yang sebelumnya hanya dua semester ditingkatkan menjadi empat semester mulai tahun ajaran 2017/2018, serta memformulasikan standar kreatifitas tenaga pengajar guna meningkatkan minat mahasiswa dalam mengikuti pembelajaran, sehingga tercapai hasil yang optimal.

Fenomena yang sangat jelas teramati di sekitas kampus STMIK STIKOM Indonesia dimana mahasiswa selalu menikmati suasana kampus sambil memainkan gadget mereka baik laptop maupun handphone di setiap sudut serta perpustakaan dari kampus. Salah satu yang sangat sering dilakukan dengan menggunakan gadget mereka selain mengerjakan tugas atau media sosial adalah menonton video, terutama video online. Salah satu penyedia video online yang sangat popular di dunia adalah Youtube.

Mahasiswa STMIK STIKOM Indonesia merupakan generasi milenial yang sangat identik dengan perkembangan teknologi. Salah satu teknologi yang berkembang pesat adalah penggunaan video. Media inilah yang bisa menjadi media pembelajaran bahasa Inggris yang mampu meningkatkan pembelajaran bahasa Inggris baik pembelajaran dalam kelas ataupun pembelajaran mandiri. Pembelajaran mandiri dengan video online mestinya akan mampu meningkatkan kapasitas pembelajaran dimana mereka bisa belajar dimanapun mereka berada, asalkan memiliki jaringan internet.

Fenomena di atas merupakan suatu strategi yang bisa dilakukan oleh para pengajar bahasa 
Inggris untuk mengarahkan mahasiswa dalam belajar bahasa Inggris melalui media video. Aplikasi dari strategi ini adalah dengan menyelipkan video pada pembelajaran bahasa Inggris, serta memberikan link-link rekomendasi kepada mereka tentang video yang bagus untuk mereka belajar. Pembelajaran melalui video akan melibatkan pembelajaran tentang intonasi, ekspresi dan gaya bahasa.

Berdasarkan uraian diatas, penelitian yang dilakukan bertujuan untuk; 1 . Mengetahui seberapa besar ketertarikan makasiswa STMIK STIKOM Indonesia terhadap pembelajaran bahasa Inggris melalui video online Youtube, 2. Mengetahui berapa lama durasi video online Youtube yang menarik terhadap mahasiswa untuk didengarkan, serta 3. Mengetahui jenis video online bahasa Inggris apa yang digemari oleh mahasiswa STMIK STIKOM Indonesia?

\section{Tinjauan Pustaka}

Sherer dan Shea (2011) menyatakan bahwa video online merupakan suatu alat pembelajaran baru yang sangat bagus diterapkan dalam pembelajaran generasi saat ini. Alasan ini didasarkan pada pilihan materi yang menarik dan bervariasi, mudah diakses serta mampu meningkatkan kedekatan dalam diskusi kelas. Dalam mengelola kelas yang dikombinasikan dengan pemanfaatan video online dapat dilakukan dengan pemberian empat jenis penugasan yang diberikan kepada mahasiswa antara lain: a. Tugas mendengarkan dan menulis, $b$. Tugas untuk menunjukkan kreatifitas, c. Tugas untuk mengkoleksi dan mengarsip, d. Tugas presentasi singkat.

\section{Youtube}

Youtube merupakan salah satu media social online yang berbasis audio visual yang paling popular dikalangan generasi masa kini. Terlebih lagi dikalangan mahasiswa STMIK STIKOM Indonesia, dimana melalui observasi, hampir semua mahasiswa menggunakan smartphone dan memiliki aplikasi online youtube. Berdasarkan data play store pada tanggal 16 Juni 2018, aplikasi youtube telah di download melebihi satu miliar pengguna, dengan rating 4.3 dari 24.866 .360 reviewer. Aplikasi ini sudah menjadi tren yang sangat tinggi sehingga melahirkan banyak pebisnis online yang menggunakan aplikasi tersebut, yang sering disebut dengan $V L O G$, atau menjadi reviewer.

Bonk (2008) dalam penelitiannya telah membuktikan bahwa penggunaan video online youtube dalam meningkatkan efektifitas dalam proses pembelajaran. Penelitian tersebut membuktikan bahwa penggunaan video online youtube mampu memaksimalkan daya ingat pelajar, serta kemampuan artifisial. Adapun lama video yang menjadi pilihan pelajar (1000 responden) adalah video-video dengan durasi $1-4$ menit, yang dianggap sangat menarik dan tidak membosankan. Jenis-jenis video yang menjadi pilihan responden adalah video-video yang besifat humor, informative, isu terkini, serta hubungan spesial.

Snelson (2011) menjelaskan sejak di launching nya media online berbasis video YouTube di tahun 2005, situs ini sudah berhasil menunjukkan popularitasnya dikalangan pengguna internet, sehingga menjadi situs nomor satu dalam situs berbagi video online. Diakhir lima tahun pertama situs ini dinikmati para penggunanya, YouTube telah mampu menerima dua miliar penonton setiap harinya, dan user mengunggah lebih dari 35 jam video setiap menitnya. Di lima tahun pertama juga YouTube telah dipakai di lebih dari 300 universitas di dunia telah menggunakan fasilitas ini sebagai bagian dari pembelajaran dan upaya peningkatan kualitas pengajaran.

Lestari (2017) telah melakukan penelitian tentang efektifitas penggunaan video online youtube dalam pengajaran di sebuah perguruan tinggi. Dalam penelitian tersebut, penggunaan youtube tebukti menjadi pendukung yang sangat penting dalam pembelajaran bahasi inggris. Secara rinci penelitian tersebut mengungkap dua poin antara lain: a. Youtube Sebagai Sumber Belajar, b. Persepsi Mahasiswa tentang Penggunaan Youtube sebagai Sumber Belajar. Hasil penelitian tersebut menunjukkan $74 \%$ mahasiswa setuju dengan penggunaan youtube yang mampu meningkatkan minat belajar bahasa inggris mereka, dan $22.2 \%$ menyatakan sangat setuju. $96 \%$ responden menyatakan bahwa penggunaan youtube sangat menarik. $88.9 \%$ menyatakan bahwa video dari youtube membantu mereka memahami materi dengan lebih baik. Kesimpulan dari penelitian ini, semua mahasiswa mempunyai persepsi positif terhadap pemakaian youtube, dan ungkapan yang paling banyak muncul dalam komentar adalah "menarik" 


\section{Generasi Milenial}

Generasi saat ini dikenal dengan generasi milenial, dimana disebut juga dengan generasi yang melek dengan teknologi. Generasi ini dikenal dengan istilah milenial karena mereka lahir di selasela pergantian jaman ke jaman millennium. Panjaitan dan Prasetya (2017) menyebutkan bahwa ciri-ciri dari generasi milenial antara lain:

1. Tingkat pendidikan dan pengetahuan yang lebih tinggi dari generasi sebelumnya.

2. Terdapat keberagaman dari sisi etnik yang lebih baik dari sebelumnya

3. Sering disebut dengan echo boomers atau millennial generation dikarenakan mereka lahir setelah perang dunia II dan merasakan perkembangan teknologi dan pergantian tahun millennium.

Karakter dari generasi millennium adalah kecanduan internet, percaya diri, harga diri tinggi dan lebih terbuka dan bertoleransi terhadap perubahan. Dari pendapat ini dapat kita lihat bahwa peranan internet sangat tinggi dalam menjalani kehidupan sehari-hari. Seperti halnya mahasiswa STMIK STIKOM Indonesia dimana hampir semuanya menggunakan teknologi dalam melakukan aktifitas sehari-hari, dalam mencari informasi maupun menjalin hubungan dengan yang lain. Dari hasil pengamatan, semua mahasiswa menggunakan smartphone maupun laptop.

Kilber et al (2014) mengungkapkan bahwa generasi milenial juga dikenal dengan Generasi Y, dimana memerlukan trik-trik tertentu dalam mengarahkan mereka. Disebutkan bahwa generasi $\mathrm{Y}$ adalah mereka yang lahir diantara tahun 1980 sampai 2000. Generasi Y disebut dengan berbagai istilah antara lain net generation (NetGen), screenagers, Google Generation, digital native, serta yang paling umum dan popular disebut dengan generasi milenial. Karakteristik dari generasi Y meliputi kecerdasan teknologi, bekerja multi tasking, team players, mengurus kebutuhan sendiri (autonomous), self center, ambisius, informal,serta menyukai pekerjaan yang memberikan arti terhadap kehidupannya.

Barnes et.al (2007) menyatakan bahwa generasi milenial juga dikenal dengan generasi internet (Net Generation) dimana meraka memiliki ciri-ciri sangat berorientasi pada pendidikan. Hal ini sudah tercermin ketika mereka memulai menginjak dunia pendidikan di tingkat dasar.

\section{Metode Penelitian}

Rancangan Penelitian

Metode deskriptif kualitatif akan digunakan dalam penelitian ini dengan tahapan sebagai berikut: a) Persiapan; Lokasi penelitian dilakukan pada kampus STMIK STIKOM Indonesia yang beralamat di Jalan Tukad Pakerisan no 97, Denpasar Selatan, Bali. b) Populasi dan Sampel; Populasi penelitian adalah semua mahasiswa aktif STMIK STIKOM INDONESIA tahun ajaran 2018- 2019, dengan sampel yang dipilih adalah mahasiswa semester tiga dan lima dengan mengambil dua kelas. c) Durasi penelitian yang disesuaikan selanjutnya dengan setiap tahapan kegiatan penelitian yang akan dilakukan. d) Pengumpulan data, e) Selanjutnya data yang telah terkumpul akan diolah dan dianalisa berdasarkan metode yang sudah dipilih.

\section{Teknik Pengumpulan Data}

Pengumpulan data dilakukan dengan metode kualitatif, dengan langkah-langkah sebagai berikut: a) Pengamatan dan dokumentasi, b) Mengamati dan mendokumentasikan kemampuan bahasa Inggris mahasiswa, c) Wawancara, d) Kuesioner. Hasil dari pengumpulan data kuesioner akan diolah dengan menggunakan skala Likert.

\section{Pengolahan Data}

Data yang terkumpul selanjutnya diklasifikasi berdasarkan kajian Linguistik. Proses pengolahan data dalam penelitian ini, antara lain: mengkompilasi dan mengklasifikasi hasil penelitian berdasarkan teknik pada pengumpulan data yaitu dengan menggunakan skala Likert.

\section{Analisis Data}

Analisa data akan dilakukan dengan metode deskriptif kualitatif dengan menguraikan hasil temuan di lapangan dan memberi kesimpulan tentang apakah video online Youtube bisa membantu mahasiswa STMIK STIKOM INDONESIA dalam meningkatkan minat dan pemahaman dalam mempelajari bahasa Inggris.

\section{Hasil Dan Pembahasan}

Penelitian yang dilakukan pada mahasiswa STMIK STIKOM Indonesia telah mengambil jumlah sampel 50 mahasiswa yang terbagi menjadi dua kelas pada program studi Teknik Informatika. Kuisioner di desain dengan jumlah 20 pertanyaan 
yang mencakup analisa tentang ketertarikan mahasiswa terhadap video online youtube, durasi video pembelajaran yang tepat, serta jenis-jenis video online yang mereka anggap sebagai video yang menarik.

\section{Ketertarikan Mahasiswa Terhadap Video} Online Youtube dalam Pembelajaran Bahasa Inggris.

Sebagai parameter dalam melihat ketertarikan mahasiswa terhadap video online youtube dalam bahasa inggris dijabarkan dalam 16 item pertanyaan, dimana semua pertanyaan tersebut diklasifikasikan menjadi dua bagian yaitu ketertarikan mahasiswa untuk menikmati video online youtube dalam pembelajaran bahasa inggris, serta fasilitas pendukung yang dimiliki kampus dalam mempresentasikan video tersebut di dalam kelas. Hasil dari kuisioner tersebut telah diolah dengan menggunakan skala Likert, dan menunjukkan hasil yang sangat positif $74.01 \%$, dimana mahasiswa tergolong sangat positif menyambut penggunaan video online youtube dalam proses pembelajaran bahasa inggris didalam kelas.

\section{a. Ketertarikan Terhadap Video Online Youtube \\ Ketertarikan mahasiswa menikmati video} online youtube tercermin dalam 13 item pertanyaan, dimana hasil dari jawaban mahasiswa menunjukkan bahwa mereka sangat menyukai video youtube dalam mempelajari sesuatu, termasuk mempelajari bahasa Inggris. Hasil penelitian menunjukkan bahwa nilai ketertarikan terhadap video online youtube adalah $76.28 \%$.

\section{b. Fasilitas Pendukung}

Fasilitas pendukung tidak bisa dilepaskan dari proses penggunaan video online youtube dalam pembelajaran bahasa Inggris. Adapun yang menjadi pendukung dalam proses tersebut adalah sebagai berikut:

1. Komputer dan program yang ada didalamnya

2. Sound system atau speaker

3. Kualitas LCD projector yang ada didalam kelas

Fasilitas-fasilitas tersebut akan menentukan apakah video yang dibawakan didalam kelas mampu dinikmati dengan baik atau tidak karena menjadi faktor penentu terlaksananya program tersebut sebagai media pembelajaran mahasiswa. Hasil penelitian menunjukkan bahwa persentasi terhadap fasilitas pendukung dalam penggunaan video online youtube dalam pembelajaran bahasa Inggris masih lebih rendah $4.54 \%$ yaitu $71.73 \%$, dari pada ketertarikan mahasiswa terhadap video online youtube. Dari kedua hasil indikator tersebut, ketertarikan mahasiswa terhadap penggunaan video online youtube dalam proses pembelajaran bahasa inggris adalah $74.01 \%$.

\section{Durasi Ideal Video Online Dalam \\ Pembelajaran Bahasa Inggris}

Durasi ideal selipan video online dalam pembelajaran bahasa Inggris menjadi salah satu hal yang harus diperhatikan. Video yang terlalu panjang akan memberikan efek bosan terhadap yang mendengarkan terutama dalam pembelajaran bahasa Inggris, sedangkan video yang terlalu singkat akan terlalu sedikit pesan yang diterima oleh yang mendengarkan. Hasil penelitian menunjukkan bahwa menurut mahasiswa STMIK STIKOM Indonesia, durasi ideal satu sampai dua menit dipilih oleh $46 \%$ dari jumlah responden. Selanjutnya disusul dengan pilihan 2 sampai 3 minit sebanyak $24 \%$. Peringkat tiga yang dipilih oleh responden dengan persentase $14 \%$ adalah video yang memiliki durasi lebih dari 5 menit, dan disusul oleh responden yang memilih durasi kurang dari satu menit dan tiga sampai lima menit dengan masing masing responden $8 \%$.

Berdasarkan dengan hasil wawancara dengan beberapa dosen pengajar bahasa Inggris juga menunjukkan bahwa lebih dari 50\% menyatakan bahwa durasi ideal yang diselipkan kedalam video online youtube adalah antara satu sampai tiga menit. Pemilihan tersebut didasarkan pada pemikiran bahwa video disamping sebagai bagian dari materi yang disampaikan, juga berfungsi sebagai peralihan yang mampu menghindarkan mahasiswa terhadap kejenuhan dalam mengikuti mata kuliah. Disisi lain, presentasi video yang terlalu lama akan berakibat pada timbulnya kebosanan dari pelajar dalam mengikuti mata kuliah.

Berdasarkan hasil dari penelitian ini, durasi video online youtube yang dikolaborasikan dengan presentasi pengajaran di dalam kelas bahasa Inggis adalah antara satu sampai tiga menit. Dengan rekomendasi yang diberikan untuk setiap tema mata kuliah bahasa Inggris, maka para dosen hanya perlu mengikuti link yang sudah disediakan untuk men-download ataupun memutar secara online dalam perkuliahan di dalam kelas. 
3. Jenis-Jenis Video Online yang Digemari

Mahasiswa

Penelitian yang dilakukan melibatkan beberapa parameter antara lain katagori video, dialek bahasa serta model dan karakter. Ketiga karakter tersebut nantinya akan digunakan sebagai acuan dalam pemilihan video online sebagai referensi para pengajar, sehingga secara umum merupakan yang digemari mahasiswa.

a. Katagori Video Online

Katagori video online yang menjadi parameter dalam penelitian yang dilakukan serta respon dari mahasiswa menunjukkan bahwa mahasiswa sangat menggemari studi kasus, yang merupakan suatu simulasi keadaan tertentu. Dari jenis video ini, mahasiswa akan belajar tentang situasi-situasi tertentu, dan apa istilah-istilah bahasa inggris yang diperlukan pada situasi tersebut. Dari hasil kuisioner yang disebarkan, 40\% memilih studi kasus tersebut. Selanjutnya adalah tutorial/informasi $24 \%$, yang mana merupakan suatu cara-cara atau trik-trik yang yang digunakan pada situasi-situasi tertentu, misalnya cara membaca berita yang baik, cara komunikasi publik, dan yang lainnya. Komedi dipilih oleh 16\% responden, diikuti oleh kartun $12 \%$, dan reality show $4 \%$.

b. Dialek Bahasa Dalam Video

Dialek merupakan aksen yang digunakan dalam video online tersebut, yang mana aksen bahasa Inggris secara garis besar dibagi menjadi tiga, diantaranya Inggris, Amerika dan Australia.

Hasil penelitian menunjukkan bahwa $40 \%$ dari renponden lebih memilik dialek Amerika dalam menikmati video online youtube, disusul selanjutnya adalah dialek Britis dengan 30\% responden. $20 \%$ dari responden memilih dialek Indonesia, dan 5\% responden memilih dialek Australia. Akan tetapi mahasiswa yang menjadi responden tidak ada yang memilih dialek Singapura sebagai dialek yang disukai dalam video online youtube.

\section{Model dan Karakter Video}

Model dan karakter dari sebuah video akan memberikan kesan menarik untuk ditonton. Dari hasi penelitian dapat dilihat bahwa karakter lucu dan memiliki wajah yang bagus menjadi pilihan mahasiswa sebagai model dan karakter yang menarik, masing-masing 32\% dan $22 \%$. Setelah itu disusul dengan tampilan grafis $20 \%$, kartun $9 \%$ dan dengan model dan karakter sexy sebanyak $8 \%$ dari total responden.

\section{Rekomendasi Video Online Youtube dalam Pembelajaran Bahasa Inggris}

Berdasarkan pada hasil penelitian yang dilakukan, dapat diketahui bahwa minat mahasiswa dalam menonton video online youtube dalam bahasa Inggris dapat disesuaikan dengan beberapa kreteria berikut.

1. Memiliki durasi antara satu sampai tiga menit atau yang mendekati, dimana bertujuan untuk menghindarkan mahasiswa dari kebosanan, serta mampu memastikan materi bisa disisipkan.

2. Pemilihan video online youtube yang diusahakan studi kasus dan tutorial/informasi.

3. Video online yang menggunakan dialek Amerika, Inggris sebagai native speaker dari bahasa Inggris, serta dialek Indonesia dimana yang banyak dianggap lebih mudah dipahami sebagai pelajar pemula.

4. Memiliki karakter lucu, wajah yang bagus/menarik, karakter grafis serta kartun.

Berdasarkan kriteria-kriteria pemilihan video diatas, dapat diberikan beberapa rekomendasi video yang mampu memberikan efek menarik terhadap mahasiswa ketika diselipkan de dalam pelajaran antara lain:

1. Step on handling customer's complain https://www.youtube.com/watch?v=T20hV 4ynU70

Link video di atas merupakan step-step yang harus dilakukan ketika menghadapi komplin dari pelanggan. Video ini memiliki durasi 2.46 menit.

\section{Mastering reading comprehension}

https:/www.youtube.com/watch?v=w N2366hL4

Link video diatas merukapan suatu tutorial atau informasi dalam menguasai kemampuan membaca yang baik (reading comprehension skill).

3. Public speaking tips

https://www.youtube.com/watch?v=JNOXZ umCXNM

Link video diatas merupakan sebuah tutorial yang memberikan tips-tips dalam belajar berbicara di tempat umum (public speaking tips). 


\section{Active Listening}

https://www.youtube.com/watch?v=bFQ8L $0 \mathrm{q} 8 \mathrm{~Np} 0$

Video berdurasi 1.43 menit yang memberikan gambaran situasi (studi kasus) dalam menjadi pendengar yang baik, serta step yang harus dilakukan sebagai pendengar yang aktif (active listening skills)

5. What's your $F$

https://www.youtube.com/watch?v=EaOW2Ua3fQ

Video diatas merupakan video berdurasi 1 menit yang sangat cocok digunakan dalam suatu permainan dalam mendefinisikan diri mereka dengan menggunakan hurup tertentu.

6. Simple present tense

https://www.youtube.com/watch?v=k0FHG $\underline{\text { nc6iHg }}$

Video diatas memiliki durasi 2.23 menit yang merupakan contoh-contoh dari kegiatan sehari-hari, yang sangat cocok diselipkan dalam menyampaikan materi daily activities, atau yang berhubungan dengan simple present tense.

7. Custom and Tradition

https://www.youtube.com/watch? $\mathrm{v}=\mathrm{fSweEs}$ 7E0yQ

Video diatas merupakan tradisi orang Amerika dalam kehidupan mereka seharihari, yang mana sangat cocok disisipkan dalam tema custom and tradition.

8. Asking a direction

https://www.youtube.com/watch?v=6sAGc YBKVpU

Video ini merupakan video lucu berdurasi 1.42 menit yang memberikan informasi tentang petunjuk arah, yang mana akan sangat bermanfaat ketika dosen memberikan pelajaran tentang asking and giving direction.

\section{Planning and negotiation}

https://www.youtube.com/watch?v=rDMft MbFkQM

Video diatas merupakan suatu tutorial yang menggunakan karakter kartun dan grafis dalam menyampaikan informasi video tersebut. Video ini sangat cocok dalam memberikan materi planning and negotiation.
10. Examples of how to introduce yourself https://www.youtube.com/watch?v=NZ9gR 2 IGdw

Video di atas merupakan 2 menit video yang memberikan beberapa contoh bagaimana seseorang memperkenalkan diri mereka dihadapan orang lain. Video ini sangat cocok diterapkan pada semester awal, atau English 1, dimana merupakan awal dari pembelajaran.

\section{Selling strategy}

https://www.youtube.com/watch?v=Mqn9a maf9SM

Video yang berdurasi 2.25 menit ini merupakan video yang sangat cocok diberikan kepada mahasiswa ketika mereka belajar menjual sesuatu dengan menggunakan bahasa Inggris.

\section{Example of Job Interview}

https://www.youtube.com/watch?v=Rdi-

SNhe2v4

Video dengan durasi 1.45 menit di atas merupakan contoh proses interview yang dilakukan oleh seorang pelamar kerja. Video ini akan memberi gambaran hal-hal apa saja yang akan ditanyakan ketika menghadapi interview.

\section{Talking about my Family}

https://www.youtube.com/watch? $\mathrm{v}=9 \mathrm{t} 6 \mathrm{~T} 8 \mathrm{q}$ eTUWU

Video ini berdurasi 2.25 menit merupakan satu contoh bagaimana mahasiswa memperkenalkan keluarga mereka kepada orang lain.

\section{Tell about the computer}

https://www.youtube.com/watch?v=uzwiY5 9-pGk

Video dengan durasi 1.35 menit di atas merupakan satu contoh bagaimana mahasiswa menjelaskan tentang sebuah komputer

15. Talk about an experience

https://www.youtube.com/watch? $\mathrm{v}=\mathrm{fnVeC5}$ CNCp0

Video yang berdurasi kurang dari 3 menit ini merupakan contoh bagaimana kita menceritakan tentang pengalaman kita di depan banyak orang.

Video-video di atas merupakan contohcontoh video yang bisa diselipkan pada perkuliahan 
bahasa Inggris, dengan menyesuaikan topik yang akan dibawakan. Para dosen-dosen bahasa Inggris tentunya bisa dengan mudah mencari video-video yang menarik lainnya melalui situs youtube.

\section{Kesimpulan}

1. Ketertarikan mahasiswa terhadap video online youtube dalam pembelajaran bahasa Inggris sangat tinggi, dimana hasil analisa dengan skala Likert menunjukkan bahwa ketertarikan mahasiswa sebesar 74,01\%. Ketertarikan mahasiswa ini apabila dipecah menjadi dua, antara memang tertarik dengan video online youtube dengan fasilitas pendukung, menunjukkan bahwa nilai fasilitas pendukung dirasa lebih perlu ditingkatkan, yaitu dengan nilai $71,73 \%$, sedangkan ketertarikan mahasiswa terhadap videonya sendiri $76,28 \%$.

2. Durasi ideal untuk sebuah video online youtube yang disisipkan dalam pembelajaran bahasa Inggris menunjukkan bahwa satu sampai tiga menit merupakan durasi yang paling ideal, dimana secara konten sudah sangat cukup, dan disisi lain menghindarkan mahasiswa dari kebosanan apabila terlalu lama. Hal ini juga senada dengan hasil wawancara dengan beberapa dosen bahasa Inggris yang lain, yang memilih durasi tersebut sebagai durasi yang paling tepat.

3. Dari sisi jenis video online youtube yang menarik buat mahasiswa adalah video dengan studi kasus dan tutorial/informasi. Sedangkan dari sisi dialek, mahasiswa lebih memilih bahasa Inggris Amerika dan Britis, yang digunakan dalam video online tersebut.

4. Model dan karakter video yang digemari mahasiswa adalah karakter yang lucu, memiliki wajah yang bagus, serta grafis. Hal ini sangat penting dimana model dan karakter tersebut akan memberikan kesan menarik ketika ditonton.

\section{Saran}

Berdasarkan hasil penelitian dan kesimpulan yang dicapai, dapat diberikan beberapa saran sebagai berikut.

1. Manajemen STMIK STIKOM Indonesia selalu memperhatikan semua fasilitas khususnya yang berhubungan dengan audio video di ruang kelas selalu berfungsi dengan normal, sehingga mampu dimanfaatkan dengan baik terutama dalam penggunaan video.

2. Apabila ternyata para dosen terutama dosen bahasa Inggris belum begitu menguasai tentang pengoperasian fasilitas yang disediakan seperti misalnya pengaturan audio visual, para dosen harus segera memberitahukan ke pihak manajemen, dan manajemen STIKI Indonesia kemudian bersedia memberikan pelatihan pengoperasian yang benar.

3. Dalam merancang materi perkuliahan, para dosen bahasa Inggris diharapkan untuk menyelipkan video yang banyak tersedia pada situs video online youtube, dan pemilihan yang jenis video yang tepat seperti pada kesimpulan di atas, serta kemudian menyelipkan dalam presentasi power point yang diberikan di dalam kelas.

4. Setiap dosen bahasa Inggris STMIK STIKOM Indonesia harus mampu memotivasi mahasiswa untuk menggunakan media online youtube sebagai media pembelajaran bahasa Inggris yang bisa dilakukan dimana saja, tidak terbatas pada pembelajaran di ruang kelas.

\section{Daftar Pustaka}

Bonk, C. J. 2008. YouTube anchors and enders: The use of shared online video content as a macrocontext for learning. Paper presented at the American Research Association (AERA) 2008 Annual Meeting, New York, NY.

Barnes, K \& et.al. 2007. Teaching and Learning with the Net Generation. Innovate: Journal of Online Education Vol. 3 Issue 4 April/May 2007; NSU-North Southeastern University.

Kilber, J \& et.al. 2014. Seven Tips for Managing Generation Y. Journal of Management Policy and Practice vol. 15(4) 2014; Northern State University.

Sherer, P \& Shea, T. 2011. Using Online Video to Support Student Learning and Engagement. College Teaching, 59: 56-59, 2011; Routledge Taylor \& Francis Group.

Snelson, C. 2011. YouTube across the Disciplines: A Review of the Literature. MERLOT Journal of Online Learning and Teaching Vol. 7, No. 1, March 2011. 
Lestari, R. 2017. Penggunaan Youtube sebagai Media Pembelajaran Bahasa Inggris. Seminar Nasional Kedua Pendidikan Berkemajuan dan Menggembirakan (The Second Progressive and FunEducation Seminar) ISBN: 978-602-361-102-7.
Panjaitan, P dan Prasetya, A. 2017. Pengaruh Social Media Terhadap Produktivitas Kerja Generasi Millenial. Jurnal Administrasi Bisnis (JAB), Vol. 48 No. 1 Juli 2017 